\title{
BENTUK-BENTUK PELANGGARAN HUKUM DALAM PELAKSANAAN JABATAN NOTARIS
}

\author{
Ahmad Rifa'i, Staf Notaris Agung Raharjo, S.H., M.Kn., Nganjuk, E-mail: ar07829@gmail.com \\ Anik Iftitah, Fakultas Hukum Universitas Islam Blitar, Indonesia; E-mail: geest_willdaad@yahoo.com
}

\begin{abstract}
Abstrak
Sebagai pejabat umum pembuat akta autentik yang bertugas melayani kepentingan umum, Notaris dimungkinkan melakukan kesalahan dalam melaksanakan tugas jabatannya. Persoalannya kemudian adalah bagaimana bentuk-bentuk pelanggaran hukum dalam pelaksanaan jabatan Notaris dan tanggung jawab Notaris yang melakukan perbuatan melawan hukum. Penelitian yuridis normatif bentuk-bentuk pelanggaran hukum dalam pelaksanaan jabatan notaris menunjukkan bahwa perbuatan melawan hukum yang dilakukan oleh seorang Notaris dapat mencakup bidang perdata, administrasi, kode etik profesi dan pidana dengan konsekuensi sanksi sesuai lingkup bidang perbuatannya.
\end{abstract}

Kata kunci: Pelanggaran Hukum, Notaris, Sanksi

\section{PENDAHULUAN}

\section{Latar Belakang}

Undang-Undang Republik Indonesia Nomor 2 Tahun 2014 tentang Perubahan Atas Undang-Undang Nomor 30 Tahun 2004 tentang Jabatan Notaris merupakan landasan notaris untuk memberikan pelayanan pada masyarakat (selanjutnya disebut UUJN). Menurut Pasal 1 ayat (1) UUJN, Notaris adalah pejabat umum yang berwenang untuk membuat akta autentik dan memiliki kewenangan lainnya sebagaimana dimaksud dalam undang-undang ini atau berdasarkan undang-undang lainnya. ${ }^{1}$ Menurut R. Soegondo Notodisoerjo, notaris adalah pejabat umum openbare ambtenaren, karena erat hubungannya dengan wewenang atau tugas dan kewajiban utama membuat akta-akta otentik. ${ }^{2}$

Kedudukan notaris sebagai seorang pejabat umum merupakan suatu jabatan terhormat yang diberikan oleh Negara secara atributif melalui undang-undang kepada seseorang yang dipercayainya. Pentingnya keberadaan notaris terkait pada pembuatan akta otentik yang dimaksud oleh Pasal 1868 Kitab Undang-Undang Hukum Perdata (KUHPer). Menurut Pasal 15 UUJN mengenai semua perbuatan, perjanjian, dan penetapan yang diharuskan oleh suatu peraturan umum atau oleh yang berkepentingan dengan tugas menjamin kepastian tanggal, penyimpanan akta dan memberikan grosse, salinan dan kutipan. Pembuatan akta otentik di hadapan notaris, bukan saja karena diharuskan oleh peraturan perundang-undangan, tetapi juga karena dikehendaki oleh pihak yang berkepentingan demi kepastian hak dan kewajiban para pihak yang berkepentingan sekaligus bagi masyarakat secara keseluruhan. Dalam

\footnotetext{
1 Selain notaris, pejabat umum yang berwenang membuat akta otentik adalah pejabat lelang, pegawai pencatatan sipil burgerlijke stand, juru sita deurwaarder, hakim, panitera pengadilan dan lain sebagainya. (R. Supomo, Hukum Acara Perdata Pengadilan Negeri, Jakarta: Pradnya Paramita, hlm. 77).

2 R. Soegondo Notodisoerjono, Hukum Notariat di Indonesia Suatu Penjelasan, Jakarta: Raja Grafindo Persada, 1993, hlm. 8.
} 
menjalankan jabatannya, Notaris dalam melakukan pekerjaanya haruslah sesuai dengan koridor tugas dan tanggung jawab seperti yang telah dinyatakan dalam Peraturan Jabatan Notaris serta Kode Etik Notaris.

Notaris wajib menjunjung tinggi martabat jabatannya, baik didalam menjalankan jabatannya maupun diluar menjalankan jabatannya. ${ }^{3}$ Namun, sebagai pejabat umum yang bertugas melayani kepentingan umum, Notaris dimungkinkan melakukan kesalahan dalam melaksanakan tugas jabatannya. Sebagai satu contoh, adanya Notaris yang tidak lagi membaca aktanya sehingga akta itu menjadi akta di bawah tangan. Di dalam akta ia menulis bahwa akta itu "telah dibacakan oleh saya, Notaris, padahal ia tidak membacanya. Ia berbohong dan dengan itu membuat pemalsuan akta. Apalagi banyak Notaris membiarkan para penghadap menandatangani akta di hadapan asistennya, sehingga keterangan Notaris itu "telah berhadapan dengan para penghadap" perlu diragukan pula. Bahwa dengan tidak membaca akta dan tidak melihat siapa yang menandatangani akta, Notaris yang berbuat demikian menurunkan martabat pekerjaan dan jabatannya yang mulia itu. ${ }^{4}$ Seorang Notaris yang secara sadar, sengaja untuk secara bersama-sama dengan para pihak yang bersangkutan (penghadap) melakukan atau membantu atau menyuruh penghadap untuk melakukan suatu tindakan hukum yang diketahuinya sebagai tindakan yang melanggar hukum berkonsekuensi merugikan Notaris dan para pihak, juga akhirnya orang yang menjalankan tugas jabatan sebagai Notaris, bisa mendapat stigma sebagai pelanggar hukum.

Berdasarkan latar belakang tersebut di atas, permasalahan penelitian ini dirumuskan sebagai berikut. Pertama, bagaimana bentuk-bentuk pelanggaran hukum dalam pelaksanaan jabatan Notaris?; dan Kedua, bagaimana tanggung jawab notaris yang melakukan perbuatan melawan hukum?

\section{Metode Penelitian}

Jenis penelitian yang digunakan dalam penelitian ini adalah penelitian yuridis normatif, bersifat deskriptif. Pada penelitian hukum normatif, bahan pustaka merupakan data dasar yang dalam ilmu penelitian digolongkan sebagai data sekunder. Data sekunder mencakup : 5

a. Bahan hukum primer, yaitu bahan hukum yang mengikat dan terdiri dari Undang-Undang Nomor 2 Tahun 2014 tentang Perubahan atas Undang-Undang Nomor 30 Tahun 2004 tentang Jabatan Notaris dan peraturan yang setaraf;

b. Bahan hukum sekunder, yaitu bahan hukum yang mengikat dan terdiri dari dan memberikan penjelasan mengenai bahan hukum primer, seperti hasil-hasil penelitian, hasil

\footnotetext{
${ }^{3}$ R. Soegondo Notodisoerjo, Hukum Notariat di Indonesia, Jakarta: C.V. Rajawali, 1982, hlm.213.

4 Purwaningsih, "Bentuk Pelanggaran Hukum Notaris di Wilayah Provinsi Banten dan Penegakan Hukumnya", MIMBAR HUKUM, Volume 27, Nomor 1, Februari 2015, hlm. 15.

5 Soerjono Soekanto, Sri Mamudji, Penelitian Hukum Normatif, Suatu Tinjauan Singkat, Jakarta: PT RajaGrafindo Persada, 2004, hlm. 12-15.
} 
karya dari kalangan hukum mengenai pengawasan dan pembinaan terhadap Notaris dan seterusnya; dan

c. Bahan hukum tersier, yaitu bahan hukum yang mengikat dan terdiri dari dan memberikan petunjuk maupun penjelasan terhadap bahan hukum primer dan sekunder, seperti kamus, ensiklopedia, indeks kumulatif dan seterusnya.

Metode pengumpulan data yang digunakan dalam penulisan ini adalah menggunakan metode penelitian kepustakaan (library research). Untuk lebih mengembangkan data penelitian ini, dilakukan analisis secara langsung kepada informan dengan menggunakan pedoman analisis yang telah dipersiapkan terlebih dahulu.

\section{PEMBAHASAN}

\section{BENTUK-BENTUK PELANGGARAN HUKUM DALAM PELAKSANAAN JABATAN NOTARIS}

Perbuatan melawan hukum adalah perbuatan atau tindakan yang dilakukan oleh subjek hukum yang melanggar ketentuan atau peraturan yang telah ditetapkan. Syarat perbuatan dikatakan perbuatan melawan hukum yaitu adanya perbuatan, yang melawan hukum, harus ada kesalahan dan harus ada hubungan sebab akibat antara perbuatan dan kerugian. Notaris sebagai subjek hukum yaitu pendukung hak dan kewajiban sekaligus sebagai anggota dari perkumpulan Ikatan Notaris Indonesia memiliki kewajiban yang harus dipatuhi dan larangan yang harus dihindari dalam menjalankan tugas jabatannya. Perbuatan melawan hukum yang dilakukan oleh seorang Notaris dapat mencakup bidang perdata, administrasi, kode etik profesi Notaris dan pidana.

Perbuatan melawan hukum dalam ranah bidang perdata diatur dalam buku III Pasal 1352 KUHPerdata. Perbuatan melawan hukum berasal dari undang-undang, bukan karena perjanjian yang berdasarkan persetujuan dan perbuatan melawan hukum murni merupakan akibat pelanggaran perbuatan manusia yang sudah ditentukan sendiri oleh undang-undang. Notaris melakukan perbuatan melawan hukum juga dapat didasarkan pada Pasal 1365 KUHPerdata yang menyatakan tiap perbuatan melanggar hukum yang membawa kerugian kepada seorang lain, mewajibkan orang yang karena salahnya menerbitkan kerugian itu, mengganti kerugian itu. Kesalahan Notaris dalam membuat akta sehingga menyebabkan pihak lain mengalami kerugian dapat termasuk perbuatan melawan hukum karena kelalaian.

Perbuatan melawan hukum Notaris dalam bidang Administrasi dan kode etik jabatan Notaris antara lain sebagai berikut:

1. Mempunyai lebih dari 1 (satu) kantor, baik kantor cabang ataupun kantor perwakilan.

2. Memasang papan nama dan/atau tulisan yang berbunyi "Notaris/ Kantor Notaris" di luar lingkungan kantor.

3. Melakukan publikasi atau promosi diri, baik sendiri maupun secara bersama-sama, dengan mencantumkan nama dan jabatannya, menggunakan sarana media cetak dan/atau elektronik, dalam bentuk :

a. Iklan.

b. Ucapan selamat. 

c. Ucapan belasungkawa.
d. Ucapan terima kasih.
e. Kegiatan pemasaran.
f. Kegiatan sponsor, baik dalam bidang sosial, keagamaan, maupun olahraga.

4. Bekerja sama dengan biro jasa/orang/badan hukum yang pada hakekatnya bertindak sebagai perantara untuk mencari atau mendapatkan klien.

5. Menandatangani akta yang proses pembuatan minutanya telah dipersiapkan oleh pihak lain.

6. Mengirimkan minuta kepada klien untuk ditanda tangani.

7. Berusaha atau berupaya dengan jalan apapun, agar seseorang berpindah dari Notaris lain kepadanya, baik upaya itu ditujukan langsung kepada klien yang bersangkutan maupun melalui perantara orang lain.

8. Melakukan pemaksaan kepada klien dengan cara menahan dokumen- dokumen yang telah diserahkan dan/atau melakukan tekanan psikologis dengan maksud agar klien tersebut tetap membuat akta padanya.

9. Melakukan usaha-usaha, baik langsung maupun tidak langsung yang menjurus ke arah timbulnya persaingan yang tidak sehat dengan sesama rekan Notaris.

10. Menetapkan honorarium yang harus dibayar oleh klien dalam jumlah yang lebih rendah dari honorarium yang telah ditetapkan perkumpulan.

11. Mempekerjakan dengan sengaja orang yang masih berstatus karyawan kantor Notaris lain tanpa persetujuan terlebih dahulu dari Notaris yang bersangkutan.

12. Menjelekkan dan/atau mempersalahkan rekan Notaris atau akta yang dibuat olehnya. Dalam hal seorang Notaris menghadapi dan/atau menemukan suatu akta yang dibuat oleh rekan sejawat yang ternyata didalamnya terdapat kesalahan-kesalahan yang serius dan/atau membahayakan klien, maka Notaris tersebut wajib memberitahukan kepada rekan sejawat yang bersangkutan atas kesalahan yang dibuatnya dengan cara yang tidak bersifat menggurui, melainkan untuk mencegah timbulnya hal-hal yang tidak diinginkan terhadap klien yang bersangkutan ataupun rekan sejawat tersebut.

13. Membentuk kelompok sesama rekan sejawat yang bersifat ekslusif dengan tujuan untuk melayani kepentingan suatu instansi atau lembaga, apalagi menutup kemungkinan bagi Notaris lain untuk berpartisipasi.

14. Menggunakan dan mencantumkan gelar yang tidak sesuai dengan peraturan perundangundangan yang berlaku.

15. Melakukan perbuatan-perbuatan lain yang secara umum disebut sebagai pelanggaran terhadap Kode Etik Notaris, antara lain namun tidak terbatas pada pelanggaranpelanggaran terhadap :

a. Ketentuan-ketentuan dalam Undang-Undang Nomor 30 Tahun 2004 tentang Jabatan Notaris.

b. Penjelasan Pasal 19 ayat (2) Undang-Undang Nomor 30 tahun 2004 tentang Jabatan Notaris. 
c. Isi sumpah jabatan Notaris.

d. Hal-hal yang menurut ketentuan Anggaran Dasar, Anggaran Rumah Tangga dan/atau Keputusan-Keputusan lain yang telah ditetapkan oleh organisasi Ikatan Notaris Indonesia tidak boleh dilakukan oleh anggota.

Notaris sebagai pejabat umum yang menjalankan sebagian dari kekuasan negara di bidang Hukum Perdata terutama untuk membuat alat bukti otentik (akta Notaris). Dalam pembuatan akta Notaris baik dalam bentuk partij akta maupun relaas akta, Notaris bertanggungjawab supaya setiap akta yang dibuatnya mempunyai sifat otentik sebagaimana yang dimaksud dalam Pasal 1868 KUHPerdata. Kewajiban Notaris untuk dapat mengetahui peraturan hukum yang berlaku di Negara Indonesia juga serta untuk mengetahui hukum apa yang berlaku terhadap para pihak yang datang kepada Notaris untuk membuat akta. Hal tersebut sangat penting agar supaya akta yang dibuat oleh Notaris tersebut memiliki otentisitasnya sebagai akta otentik karena sebagai alat bukti yang sempurna.

Namun dapat saja Notaris melakukan suatu kesalahan dalam pembuatan akta. Kesalahankesalahan yang mungkin dapat terjadi, yaitu :

a. Kesalahan ketik pada salinan Notaris, dalam hal ini kesalahan tersebut dapat diperbaiki dengan membuat salinan baru yang sama dengan yang asli dan hanya salinan yang sama dengan yang asli baru mempunyai kekuatan sama seperti akta asli.

b. Kesalahan bentuk akta Notaris, dalam hal ini dimana seharusnya dibuat berita acara rapat tapi oleh Notaris dibuat sebagai pernyataan keputusan rapat.

c. Kesalahan isi akta Notaris, dalam hal ini mengenai keterangan dari para pihak yang menghadap Notaris, di mana saat pembuatan akta dianggap benar tapi ternyata kemudian tidak benar. ${ }^{6}$

Notaris dalam menjalankan jabatannya dapat juga terjerat dalam perkara yang diakibatkan dari perbuatan melawan hukum dalam proses pembuatan akta otentik. Dalam konteks administrasi dan kode etik yaitu diberikan batasan seorang Notaris dikategorikan melanggar ketentuan UUJN, dan kode etik Notaris secara formil atau perdata (law of tort) atas apa yang mereka lakukan terkait dengan tindakan-tindakan Notaris, seperti penambahan, pengurangan, pencoretan, pengubahan akta tidak sesuai prosedur dengan tidak dilakukan tidak dihadapan dua saksi, Notaris/saksi yang tidak cakap melakukan perbuatan hukum, Notaris mempunyai hubungan darah dengan salah satu atau para penghadap.

Perbuatan melawan hukum dalam bidang pidana yaitu seorang Notaris dapat dikenakan tindakan pidana atas perbuatan yang melanggar ketentuan dari kaedah peraturan larangan yang diterbitkan oleh negara. Setiap perbuatan pidana selalu dirumuskan secara seksama dalam undang-undang sehingga sifatnya terbatas. Dalam ranah Hukum Pidana diantaranya dapat berupa pemalsuan dokumen atau surat yang diatur dalam ketentuan Pasal 263 dan Pasal 264 Kitab Undang-Undang Hukum Pidana (KUHP). Pasal 263 ayat (1) dan (2) KUHP menyatakan bahwa :

${ }^{6}$ Mudofir Hadi, "Pembatalan Isi Akta Notaris dengan Putusan Hakim", Varia Peradilan Tahun VI Nomor 72, 1991, hlm. 142-143. 
1 Barang siapa membuat surat palsu atau memalsukan surat yang dapat menimbulkan sesuatu hak, perikatan atau pembebasan hutang, atau yang diperuntukkan sebagai bukti daripada sesuatu hal dengan maksud untuk memakai atau menyuruh orang lain memakai surat tersebut seolah-olah isinya benar dan tidak dipalsu, diancam, jika pemakaian tersebut dapat menimbulkan kerugian, karena pemalsuan surat, dengan pidana penjara paling lama enam tahun.

2 Diancam dengan pidana yang sama, barang siapa dengan sengaja memakai surat palsu atau yang dipalsukan, seolah-olah sejati, jika pemakaian surat itu dapat menimbulkan kerugian.

Sedangkan dalam penjelasan dari Pasal 264 ayat (1) dan (2) KUHP menyatakan bahwa :

1 Pemalsuan surat diancam dengan pidana penjara paling lama delapan tahun, jika dilakukan terhadap:

1) Akta-akta otentik.

2) Surat hutang atau sertifikat hutang dari sesuatu negara atau bagiannya ataupun dari suatu lembaga umum.

3) Surat sero atau hutang atau sertifikat sero atau hutang dari suatu perkumpulan, yayasan, perseroan atau maskapai.

4) Talon, tanda bukti dividen atau bunga dari salah satu surat yang diterangkan dalam 2 dan 3, atau tanda bukti yang dikeluarkan sebagai pengganti surat-surat itu.

5) Surat kredit atau surat dagang yang diperuntukkan untuk diedarkan.

2 Diancam dengan pidana yang sama barang siapa dengan sengaja memakai surat tersebut dalam ayat pertama, yang isinya tidak sejati atau yang dipalsukan seolah-olah benar dan tidak dipalsu, jika pemalsuan surat itu dapat menimbulkan kerugian.

Notaris juga dapat dikatakan melakukan penggelapan apabila melanggar ketentuan Pasal 372 dan Pasal 374 KUHP Pasal 372 yang menyatakan bahwa :

Barang siapa dengan sengaja dan melawan hukum memiliki barang sesuatu yang seluruhnya atau sebagian adalah kepunyaan orang lain, tetapi yang ada dalam kekuasaannya bukan karena kejahatan diancam karena penggelapan, dengan pidana penjara paling lama empat tahun atau pidana denda paling banyak sembilan ratus rupiah.

Sedangkan penjelasan dari Pasal 374 KUHP yang menyatakan bahwa penggelapan yang dilakukan oleh orang yang penguasaannya terhadap barang disebabkan karena ada hubungan kerja atau karena pencarian atau karena mendapat upah untuk itu, diancam dengan pidana penjara paling lama lima tahun. Selain itu perbuatan Notaris dapat dikategorikan dalam ranah pidana apabila seorang Notaris memberikan keterangan palsu di bawah sumpah yang diatur dalam ketentuan Pasal 242 KUHP yang tersirat sebagai berikut :

1 Barang siapa dalam keadaan di mana undang-undang menentukan supaya memberi keterangan di atas sumpah atau mengadakan akibat hukum kepada keterangan yang demikian, dengan sengaja memberi keterangan palsu di atas sumpah, baik dengan lisan atau tulisan, secara pribadi maupun oleh kuasanya yang khusus ditunjuk untuk itu, diancam dengan pidana penjara paling lama tujuh tahun.

2 Jika keterangan palsu di atas sumpah diberikan dalam perkara pidana dan merugikan terdakwa atau tersangka, yang bersalah diancam dengan pidana penjara paling lama sembilan tahun.

3 Disamakan dengan sumpah adalah janji atau penguatan yang diharuskan menurut aturanaturan umum atau yang menjadi pengganti sumpah. 
4 Pidana pencabutan hak berdasarkan Pasal 35 No. 1 - 4 dapat dijatuhkan.

Adapun contoh pemalsuan dokumen yang dilakukan oleh Notaris misalnya Notaris memalsukan surat setoran bea perolehan hak atas tanah dan bangunan (BPHTB) dan surat setoran pajak (SSP). Contoh penggelapan yang dilakukan oleh Notaris yaitu penggelapan BPHTB yang dibayarkan klien.

\section{TANGGUNG JAWAB NOTARIS YANG MELAKUKAN PERBUATAN MELAWAN HUKUM}

Notaris yang terbukti melakukan perbuatan melawan hukum dalam menjalankan profesinya wajib mempertanggungjawabkan perbuatannya. Dalam penjatuhan sanksi terhadap Notaris, ada beberapa syarat yang harus terpenuhi, yaitu memenuhi rumusan perbuatan itu dilarang oleh undang-undang, adanya kerugian yang ditimbulkan dari perbuatan tersebut serta perbuatan tersebut harus bersifat melawan hukum, baik formil maupun materiil. Formal dalam arti sudah memenuhi rumusan dalam undang-undang, materiil memenuhi pengujian dengan kode etik dan UUJN. Aspek batasan dalam hal pelanggaran oleh Notaris diukur berdasarkan UUJN. Ancaman sanksi atas pelanggaran oleh Notaris diberikan berdasarkan UUJN agar dalam menjalankan tugas dan jabatannya, seorang Notaris dituntut untuk dapat bertanggungjawab terhadap diri, klien, dan juga kepada Tuhan Yang Maha Esa.

Tanggung jawab hukum seorang Notaris dalam menjalankan profesinya digolongkan sebagai berikut :

a. Tanggung jawab Hukum Perdata yaitu apabila Notaris melakukan kesalahan karena ingkar janji sebagaimana yang telah ditentukan dalam ketentuan Pasal 1234 KUHPerdata atau perbuatan melanggar hukum sebagaimana yang ditentukan dalam ketentuan Pasal 1365 KUHPerdata. Terhadap kesalahan tersebut telah menimbulkan kerugian pihak klien atau pihak lain.

b. Tanggung jawab Hukum Pidana bilamana Notaris telah melakukan perbuatan hukum yang dilarang oleh undang-undang atau melakukan kesalahan/perbuatan melawan hukum baik karena sengaja atau lalai yang menimbulkan kerugian pihak lain.7

c. Tanggung jawab administrasi dan kode etik jabatan Notaris.

Tanggung jawab administrasi, perdata dan kode etik Notaris dikenai sanksi yang mengarah pada perbuatan yang dilakukan oleh yang bersangkutan, sedangkan pertanggungjawaban pidana yang dikenai sanksi pidana menyasar pada pelaku (orang) yang melakukan tindakan hukum tersebut. Sanksi administratif dan sanksi perdata bersifat reparatoir atau korektif artinya untuk memperbaiki suatu keadaan agar tidak dilakukan lagi oleh yang bersangkutan ataupun oleh Notaris lain. Regresif berarti segala sesuatunya dikembalikan kepada suatu keadaan ketika sebelum terjadinya pelanggaran. Dalam aturan hukum tertentu, disamping dijatuhi sanksi adminstratif, juga dapat dijatuhi sanksi pidana (secara komulatif) yang bersifat comdemnatoir (punitif) atau menghukum, dalam kaitan ini

${ }^{7}$ Lanny Kusumawati, Tanggung jawab Jabatan Notaris, Bandung: Refika Aditama, 2006, hlm. 49. 
UUJN tidak mengatur sanksi pidana untuk Notaris yang melanggar UUJN. Jika terjadi hal seperti itu maka terhadap Notaris tunduk kepada tindak pidana umum. ${ }^{8}$

Mengingat Notaris dalam menjalankan tugas dan jabatannya tunduk dan patuh pada UUJN maka apabila melakukan pelanggaran dalam melaksanakan tugas dan jabatannya, Notaris diancam sanksi sebagaimana tertuang dalam UUJN. Sanksi terhadap Notaris dikategorikan menjadi 2 (dua), yaitu sanksi perdata berupa penggantian biaya, ganti rugi, dan bunga merupakan akibat yang akan diterima Notaris atas tuntutan para penghadap jika akta yang bersangkutan hanya mempunyai kekuatan pembuktian sebagai akta di bawah tangan atau akta menjadi batal demi hukum, sebagaimana ditentukan dalam Pasal 41 UUJN. Selain sanksi perdata, juga ditentukan sanksi adminstrasi yaitu berupa teguran lisan, teguran tertulis, pemberhentian sementara, pemberhentian dengan hormat, sampai pemberhentian dengan tidak hormat, sebagaimana ditentukan dalam pasal-pasal dalam UU perubahan atas UUJN.

Selain itu, Notaris juga masih harus menghadapi ancaman sanksi berupa sanksi etika jika Notaris melakukan pelanggaran terhadap kode etik jabatan Notaris, dan bahkan dapat dijatuhi sanksi pidana. Namun demikian, sanksi pidana terhadap Notaris harus dilihat dalam rangka menjalankan tugas jabatannya, dan tunduk pada ketentuan pidana umum yaitu KUHP, UUJN dan UU perubahan atas UUJN tidak mengatur mengenai tindak pidana khusus untuk Notaris.

Suatu delik atau pebuatan yang dilarang oleh undang-undang dan diancam dengan pidana mempunyai unsur objektif (unsur-unsur yang terdapat di luar manusia yang dapat berupa suatu tindakan atau tindak tanduk yang dilarang dan diancam dengan sanksi pidana, seperti memalsukan surat, sumpah palsu, pencurian) dan unsur subjektif toerekeningsvatbaarheid dan kesalahan (schuld). ${ }^{9}$ Batasan-batasan pemidanaan terhadap perbuatan yang dilakukan oleh Notaris adalah berupa ada tindakan hukum dari Notaris terhadap aspek formal akta yang sengaja, penuh kesadaran dan keinsyafan serta direncanakan, bahwa akta yang dibuat dihadapan Notaris atau oleh Notaris bersama-sama (sepakat) untuk dijadikan dasar untuk melakukan suatu tindak pidana. Ada tindakan hukum dari Notaris dalam membuat akta di hadapan atau oleh Notaris yang jika diukur berdasarkan UUJN tidak sesuai dengan UUJN. Tindakan Notaris tersebut tidak sesuai menurut instansi yang berwenang untuk menilai tindakan suatu Notaris, dalam hal ini Majelis Pengawas Notaris.

Penjatuhan sanksi pidana terhadap Notaris dapat dilakukan sepanjang batasan-batasan sebagaimana tersebut dilanggar, artinya di samping memenuhi rumusan pelanggaran yang tersebut dalam UUJN dan kode etik jabatan Notaris juga harus memenuhi rumusan yang tersebut dalam KUHP. Apabila tindakan pelanggaran yang dilakukan oleh Notaris memenuhi rumusan suatu tindak pidana, tetapi jika ternyata berdasarkan UUJN dan menurut penilaian dari Majelis Pengawas Daerah bukan suatu pelanggaran. Maka Notaris yang bersangkutan

8 Ibid, hlm. 123-124.

${ }_{9}^{9}$ Liliana Tedjosapatro, Mal Praktek Notaris dan Hukum Pidana, Semarang: CV Agung, 1991, hlm. 51. 
tidak dapat dijatuhi hukuman pidana, karena ukuran untuk menilai sebuah akta harus didasarkan pada UUJN dan kode etik jabatan Notaris.

Bentuk pertangggungjawaban terhadap Notaris yang melakukan perbuatan melawan hukum dalam pembuatan akta otentik adalah seorang Notaris dapat dikenakan pertanggungjawaban secara perdata berupa sanksi untuk melakukan penggantian biaya atau ganti rugi kepada pihak yang dirugikan atas perbuatan melawan hukum yang dilakukan oleh Notaris. Pertanggungjawaban secara administrasi berupa pemberian sanksi teguran lisan, teguran tertulis, pemberhentian sementara, pemberhentian dengan hormat dan pemberhentian dengan tidak hormat sebagai seorang Notaris. Pertanggungjawaban terhadap kode etik profesi Notaris berupa pemberian sanksi teguran, peringatan, pemecatan sementara (schorsing), pemecatan (onzetting) dan pemberhentian dengan tidak hormat dari keanggotaan perkumpulan. Sedangkan pertanggungjawaban secara pidana seorang dapat berupa pemberian sanksi pidana penjara atau kurungan atas perbuatan melawan hukum yang dilakukannya. Hal-hal tersebut berdasarkan temuan-temuan dalam yurisprudensi mengenai pertanggungjawaban terhadap Notaris yang melakukan perbuatan melawan hukum.

Tindakan pelanggaran yang dilakukan oleh Notaris terhadap ketentuan-ketentuan pasalpasal dalam UUJN, yang menyebabkan suatu akta hanya mempunyai kekuatan pembuktian sebagai akta di bawah tangan atau akta menjadi batal demi hukum, maka pihak yang merugikan dapat menuntut penggantian biaya, ganti rugi dan bunga pada Notaris. Dalam hal suatu akta Notaris dibatalkan oleh putusan hakim di pengadilan,10 maka jika menimbulkan kerugian bagi para pihak yang berkepentingan, Notaris dapat dituntut untuk memberikan ganti rugi, sepanjang hal tersebut terjadi disebabkan oleh kesalahan Notaris. Namun dalam hal pembatalan akta Notaris oleh pengadilan dengan alasan bukan merupakan kesalahan Notaris, maka para pihak yang berkepentingan tidak dapat menuntut Notaris untuk memberikan ganti rugi.

Seorang Notaris baru dapat dikatakan bebas dari pertanggungjawaban hukum apabila akta otentik yang dibuatnya dan atau dibuat dihadapannya telah memenuhi syarat formil. Akibat hukum terhadap perbuatan melawan hukum yang dilakukan oleh Notaris dalam pembuatan akta otentik pada dasarnya terjadinya suatu perkara dimana pejabat umum telah mencari-cari keuntungan serta menyalahgunakan kewenangan yang telah diatur dalam UUJN dan seorang klien atau penghadap lainnya merasa dirugikan atas terbuatnya suatu akta yang mengandung unsur perbuatan melawan hukum yang dilakukan oleh Notaris, sehingga berakibat akta otentik yang dibuat oleh Notaris dapat menjadi batal atau dapat dibatalkan.

Kasus Notaris berkaitan dengan akta otentik yang dibuatnya dan aktanya menimbulkan perkara perdata atau pidana maka aktanya batal demi hukum karena kita melihat dari sisi syarat sah perjanjian yang terdapat dalam Pasal 1320 yang berisi kesepakatan para pihak, kecakapan bertindak, adanya suatu hal tertentu yang diperjanjikan dan adanya suatu sebab yang halal terhadap perjanjian tersebut. Jika suatu akta menimbulkan suatu pidana maka

10 Kewenangan untuk menyatakan suatu akta Notaris tersebut batal demi hukum, dapat dibatalkan atau akta Notaris tersebut dinyatakan tidak mempunyai kekuatan hukum merupakan kewenangan hakim. 
persyaratan perjanjian dilihat unsur-unsur perjanjian yang terkandung didalamnya. Para ahli hukum seperti Sudikno Mertokusuno, Mariam Darus, dan J.J. Satrio bersepakat bahwa unsurunsur perjanjian itu terdiri dari unsur esensialia, ${ }^{11}$ unsur naturalia, ${ }^{12}$ dan unsur aksidentalia ${ }^{13} .{ }^{14}$

Berdasarkan pandangan asas praduga sah (Vermoeden van Rechtmatigheid) atau Presumptio Iustae Causa, ${ }^{15}$ akta otentik yang dibuat oleh Notaris harus dianggap sah dan mengikat para pihak sebelum dapat dibuktikan ketidakabsahan dari aspek lahiriah, formal dan materil akta otentik tersebut. Dalam hal ketentuan Pasal 41 UUJN yang menyatakan jika Notaris melanggar ketentuan Pasal 38, Pasal 39, dan Pasal 40 mengakibatkan akta hanya mempunyai kekuatan pembuktian sebagai akta di bawah tangan, maka akta Notaris hanya mempunyai kekuatan pembuktian sebagai akta dibawah tangan. Namun apabila para pihak dapat membuktikan ketidakbenaran akta otentik tersebut dalam persidangan di pengadilan dan mengakibatkan akta tersebut dapat dibatalkan serta kekuatan pembuktian sebagai akta dibawah tangan tidak akan berlaku lagi. Asas praduga sah tersebut berkaitan dengan akta yang dapat dibatalkan, merupakan suatu tindakan mengandung cacat yaitu tidak berwenangnya Notaris untuk membuat akta secara lahiriah, formal, materiil dan tidak sesuai dengan aturan hukum tentang pembuatan akta Notaris.

Akibat hukum terhadap akta otentik yang dibuat oleh Notaris secara melawan hukum, menyebabkan akta otentik menjadi akta dibawah tangan serta akta tersebut dapat dibatalkan, sejalan dalam pandangan teori kewenangan. Dalam teori kewenangan, Notaris dalam membuat akta otentik termasuk dalam kewenangan secara atribusi, berdasarkan ketentuan Pasal 15 ayat (1) UUJN. Terjadinya suatu akibat hukum yaitu berupa akta otentik menjadi akta dibawah tangan dan akta tersebut dibatalkan diakibatkan oleh penyalahgunaan wewenang yang dilakukan oleh Notaris, dimana Notaris telah melanggar ketentuan perundangundangan yang mengakibatkan kerugian bagi para pihak dan mengakibatkan berubahnya kekuatan pembuktian akta dan adanya pembatalan akta otentik tersebut oleh pengadilan. Akibat hukum ini juga sejalan dengan konsep perlindunganu. Sesuai konsep perlindungan hukum ${ }^{16}$ maka akibat hukum berupa pembatalan akta otentik dapat melindungi para pihak

11 Unsur esensialia adalah unsur yang mutlak harus ada untuk terjadinya perjanjian, agar penjanjian itu sah dan ini merupakan syarat sahnya perjanjian.

12 Unsur naturalia adalah unsur yang lazim melekat pada perjanjian, yaitu unsur yang tanpa diperjanjikan secara khusus dalam perjanjian secara diam-diam dengan sendirinya dianggap ada dalam perjanjian. Unsur ini merupakan sifat bawaan (natuur) atau melekat pada perjanjian. Misalnya penjual harus menjamin cacat-cacat tersembunyi kepada pembeli.

13 Unsur aksidentalia, artinya unsur yang harus dimuat atau dinyatakan secara tegas di dalam perjanjian oleh para pihak. Misalnya jika terjadi perselisihan, para pihak telah menentukan tempat yang dipilih.

14 Kartini Muljadi dan Gunawan Widjaja, Perikatan yang Lahir dari Perjanjian, Jakarta: PT Raja Grafindo Persada, 2010, hlm. 84.

${ }_{15}$ Asas praduga sah adalah asas yang menganggap sah suatu produk hukum sebelum adanya putusan pengadilan yang mempunyai kekuatan hukum tetap yang menyatakan tidak sah.

16 Satijipto Raharjo yang menjelaskan bahwa perlindungan hukum memberikan pengayoman terhadap hak asasi manusia yang dirugikan orang lain dan perlindungan itu diberikan kepada masyarakat agar 
yang merasa dirugikan oleh perbuatan melawan hukum seorang Notaris dalam proses pembuatan akta otentik.

Akibat hukum terhadap terhadap akta otentik yang dibuat oleh seorang Notaris yang melakukan perbuatan melawan hukum adalah hilangnya keotentikkan akta tersebut dan menjadi akta dibawah tangan sesuai dengan ketentuan Pasal 41 UUJN serta akta otentik tersebut dapat dibatalkan apabila pihak yang mendalilkan dapat membuktikannya dalam persidangan di pengadilan, karena pembuatan suatu akta otentik harus memuat ketiga unsur tersebut di atas (lahiriah, formil dan materiil) atau salah satu unsur tersebut tidak benar dan menimbulkan perkara pidana atau perdata yang kemudian dapat dibuktikan ketidakbenarannya. Sehingga dalam menjalankan jabatanya seorang Notaris harus tunduk pada ketentuan undang-undang dan akta tersebut dibuat oleh dan dihadapan Notaris sesuai dengan prosedur dan tata cara pembuatan akta otentik agar keotentikannya tidak menjadi akta di bawah tangan atau akta tidak sampai dibatalkan.

\section{PENUTUP}

Perbuatan melawan hukum Notaris adalah perbuatan atau tindakan yang dilakukan oleh Notaris yang melanggar UUJN, atau peraturan perundang-undangan di Indonesia, dan/atau Kode Etik Notaris. Perbuatan melawan hukum yang dilakukan Notaris dapat mencakup bidang perdata, administrasi, kode etik profesi Notaris dan pidana. Notaris yang terbukti melakukan perbuatan melawan hukum dalam menjalankan profesinya wajib mempertanggungjawabkan perbuatannya.

Tanggung jawab notaris yang melakukan perbuatan melawan hukum dalam bidang perdata, sanksinya berupa penggantian biaya, ganti rugi, dan bunga akibat yang akan diterima Notaris atas tuntutan para penghadap jika akta yang bersangkutan hanya mempunyai kekuatan pembuktian sebagai akta di bawah tangan atau akta menjadi batal demi hokum. Tanggung jawab notaris yang melakukan perbuatan melawan hukum dalam bidang administrasi, sanksinya berupa teguran lisan, teguran tertulis, pemberhentian sementara, pemberhentian dengan hormat, sampai pemberhentian dengan tidak hormat. Sedangkan pertanggungjawaban dalam konteks kode etik profesi Notaris berupa pemberian sanksi teguran, peringatan, pemecatan sementara (schorsing), pemecatan (onzetting) dan pemberhentian dengan tidak hormat dari keanggotaan perkumpulan. Dan, pertanggungjawaban secara pidana, dapat berupa pemberian sanksi pidana penjara atau kurungan atas perbuatan melawan hukum yang dilakukannya.

dapat menikmati semua hak-hak yang diberikan oleh hukum, dibutuhkan untuk mereka yang lemah dan belum kuat secara sosial, ekonomi dan politik untuk memperoleh keadilan sosial. 


\section{DAFTAR PUSTAKA}

\section{Buku dan Jurnal:}

Hadi, Mudofir "Pembatalan Isi Akta Notaris dengan Putusan Hakim", Varia Peradilan Tahun VI Nomor 72, 1991.

Kusumawati, Lanny, Tanggung jawab Jabatan Notaris, Bandung: Refika Aditama, 2006.

Muljadi, Kartini dan Widjaja, Gunawan, Perikatan yang Lahir dari Perjanjian, Jakarta: PT Raja Grafindo Persada, 2010.

Muljadi, Kartini dan Widjaja, Gunawan, Perikatan yang Lahir dari Perjanjian, Jakarta: PT Raja Grafindo Persada, 2010.

Notodisoerjo, R. Soegondo, Hukum Notariat di Indonesia, Jakarta: C.V. Rajawali, 1982.

Notodisoerjono, R. Soegondo, Hukum Notariat di Indonesia Suatu Penjelasan, Jakarta: Raja Grafindo Persada, 1993.

Patton, George Whitecross, A Text-Book af Jurisprudence, second edition, Oxford at the Clarendon Press, 1953.

Prodjodikoro, Wirjono, Azas-azas Hukum Perjanjian, Sumur Bandung, 1989.

Purwaningsih, "Bentuk Pelanggaran Hukum Notaris di Wilayah Provinsi Banten dan Penegakan Hukumnya", MIMBAR HUKUM, Volume 27, Nomor 1, Februari 2015.

Purwaningsih, "Bentuk Pelanggaran Hukum Notaris di Wilayah Provinsi Banten dan Penegakan Hukumnya", MIMBAR HUKUM, Volume 27, Nomor 1, Februari 2015.

Soekanto, Soerjono, Mamudji, Sri, Penelitian Hukum Normatif, Suatu Tinjauan Singkat, Jakarta: PT RajaGrafindo Persada, 2004.

Subekti, R., Hukum Perjanjian, Jakarta: Intermasa, 2005.

Supomo, R. , Hukum Acara Perdata Pengadilan Negeri, Jakarta: Pradnya Paramita.

Supomo, R., Hukum Acara Perdata Pengadilan Negeri, Jakarta: Pradnya Paramita.

Tedjosapatro, Liliana, Mal Praktek Notaris dan Hukum Pidana, Semarang: CV Agung, 1991.

\section{Peraturan Perundang-Undangan:}

Kitab Undang-Undang Hukum Perdata

Kitab Undang-Undang Hukum Pidana

Undang-Undang Nomor 2 Tahun 2014 tentang Perubahan atas Undang-Undang Nomor 30

Tahun 2004 tentang Jabatan Notaris 